\title{
Decision Support System of Selecting Pesticidefor Rice Pests Using WEB-Based Case Based Reasoning (CBR) Method
}

\author{
Moh. Alifuddin', Mirfan Mirfan², Sitti Zuhriyah³ ${ }^{3}$, Pujianti Wahyuningsih 4 \\ \{alifuddin@handayani.ac.id ${ }^{1}$,mirfan@handayani.ac.id ${ }^{2}$,zuhriyah@handayani.ac.id ${ }^{3}$, \\ uji.wahyuningsih@gmail.com ${ }^{4}$ \} \\ 1,2,3,4 STMIK Handayani, Adhyaksa Baru street No 1. Makassar, Indonesia
}

\begin{abstract}
Rice is one of the crops which are the main staple food in Indonesia. For Indonesian, rice that processed into being cooked rice is compulsory food. This rice is one of the crops which are most susceptible to pests. This study aims to design and implement a decision support system for the selection of pesticidesrice for pests used the Case Based Reasoning (CBR) method. The text editor used in building this system is sublime text, while the programming language uses PHP, Java Script, and MYSQL for database processing. This method is very appropriate for building information based on cases and solutions in the past forgetting back solutions to new cases. The results of this study are a web-based system that provides information on pests which attacked rice and the support system for deciding the selection of pesticides on rice pests using the CBR method. This system will help for choosing pesticides.
\end{abstract}

Keywords: Case Based Reasoning (CBR), Rice Pests, Decision Support System (DSS)

\section{Introduction}

Rice is one of the crops which are the main staple food in Indonesia, nowadays, Indonesian consume 30 tons rice per year. It indicates the needs of rice increases every year [1]. Ratio of rice consumption increases while the rice production in several of regiondoes not increase. It is caused some factors, one of them is the rice are attacked by pest.

The rice in Indonesia are attacked by pest easily because the weather factor. The unpredictable weather causes the pest raise quickly, attacks the crops, hampers the rice growth and finally, the harvest will decrease. The government has made every effort to help the farmers to solve the pest problem. One of the many solutionsare giving socialization about the pesticides for the rice.

The government effort to inform the kind of pesticides, the way of using and the composition has not been optimum. So, we sometimes find the farmers miss aboutthe information of pesticides using. It happens because the socialization model is still conventional, need more time, and the spreading does not increase. So, we need the system of information spreading more effective and can reach all communities, especially the farmers. Based on this case, the researchers make the decision support system of selecting pesticide for rice pests using the CBR method. 


\subsection{Research Method}

\subsection{Use Case system}

On the use case system, we found that the farmers just know the kind of the pests and pesticides without knowingthe exact pesticide for the rice pest. It occurs because the government has limitedness on the time and space to inform the farmers about the pesticides.

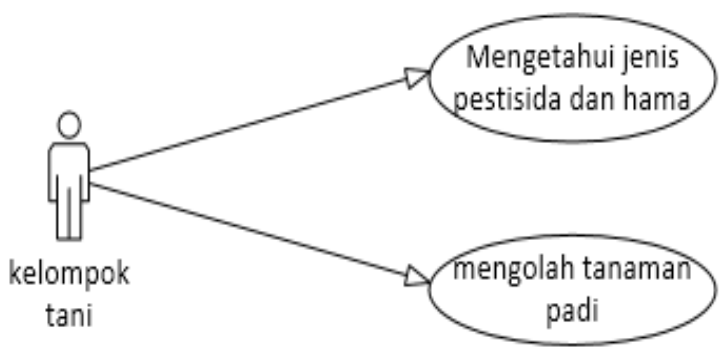

Figure 3.1. Usecase Diagram

The explanationdiagram of the use case system on figure 3.1 are:

a. The farmer group recognize the kind of pesticides and pests.

b. The farmer group process the selected rice.

\subsection{Collecting Data Method}

There are two method of collecting data, they are:

a. Interview

We have interviewed with the experts and the farmers for gaining data about pests, the symptom, and the way to solve the pests.

b. Library Research

Library research is the method to find the data through the literatures, books, another research, articles about the Decision Support System, Case Based Reasoning, the rice pests, PHP and My SQL Program.

\section{Result and Study}

\subsection{The Model System}

The model system is an activity to make technical design based on the evaluation on analysis. 


\section{Usecase diagram}
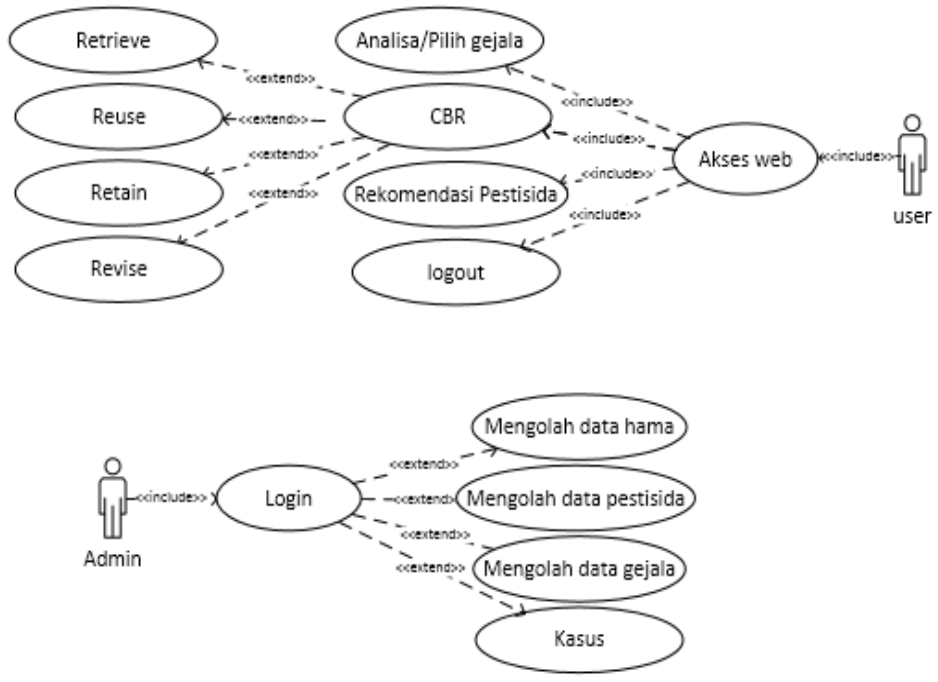

Figure 3.2. Usecase Diagram

The explanation of the use case diagram above consists of two actors. They are farmer group and administrator. The farmer group analyze, after entering, they can choose the symptom and recommended pesticide directly. The administrator logs in to enter the system, then he manages the data of pests, pesticides, symptoms and the cases.

\section{Class diagram}
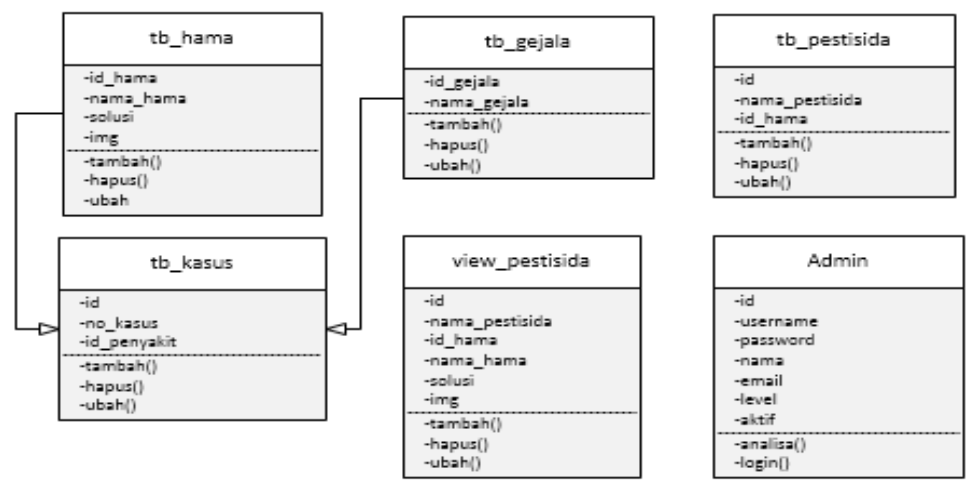

Figure 3.3 Class Diagram

Class Diagram is used to show the classes and packages in system. This class diagram describes the system statically and the relation among the classes. 


\subsection{Implementation of Algorithm}

The decision support system on this research uses CBR (Case Based Reasoning) method. $\mathrm{CBR}$ is the method which solves the problem through remembering the same incident or similar case that occurs in the past, then uses these knowledge to solve the new problem [3].

CBR or Case Based Reasoning consists of four steps [2], namely:

1. Retrieve

Retrieve is reprocessing the most similar old case with the new one.

2. Reuse

Reuse is step of making model or reusing the knowledge and information from old cases with considering the similar quality which most relevant to the new case, in order to produce new solution.

3. Revise

In the Revise step, it observes the solution then tried out in the real case (simulation). If need, the solution will be revised in order to adjust with new case.

4. Retain

Retain is saving step the new case that has been solved in order to use for next similar cases. If the new solution is failed, it can explain the fail, resolves the solution and reexamine.

The formula to count the similarity and algorithm nearest neighbor retrieval [4],[5],[6],[7] is:

$$
\text { Similarity }=\frac{S_{1} * w_{1}+S_{2} * w_{2}+\cdots+S_{n} * w_{n}}{w_{1}+w_{2}+\cdots+w_{n}}
$$

Information :

$\mathrm{S}=$ similarity

$\mathrm{W}=\mathrm{Weight}$

\section{Implementation CBR on PHP:}

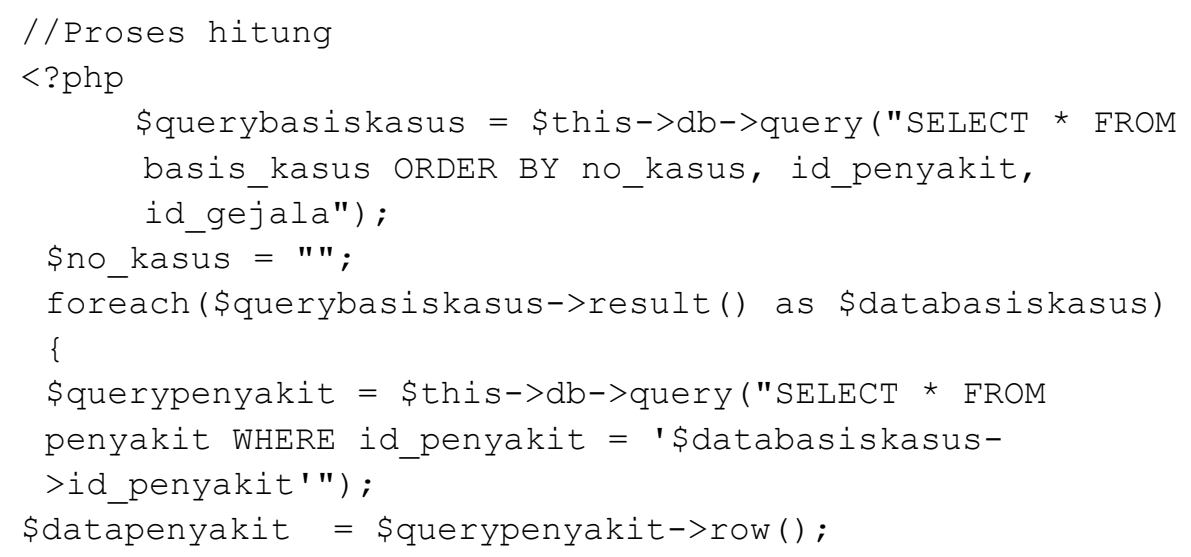




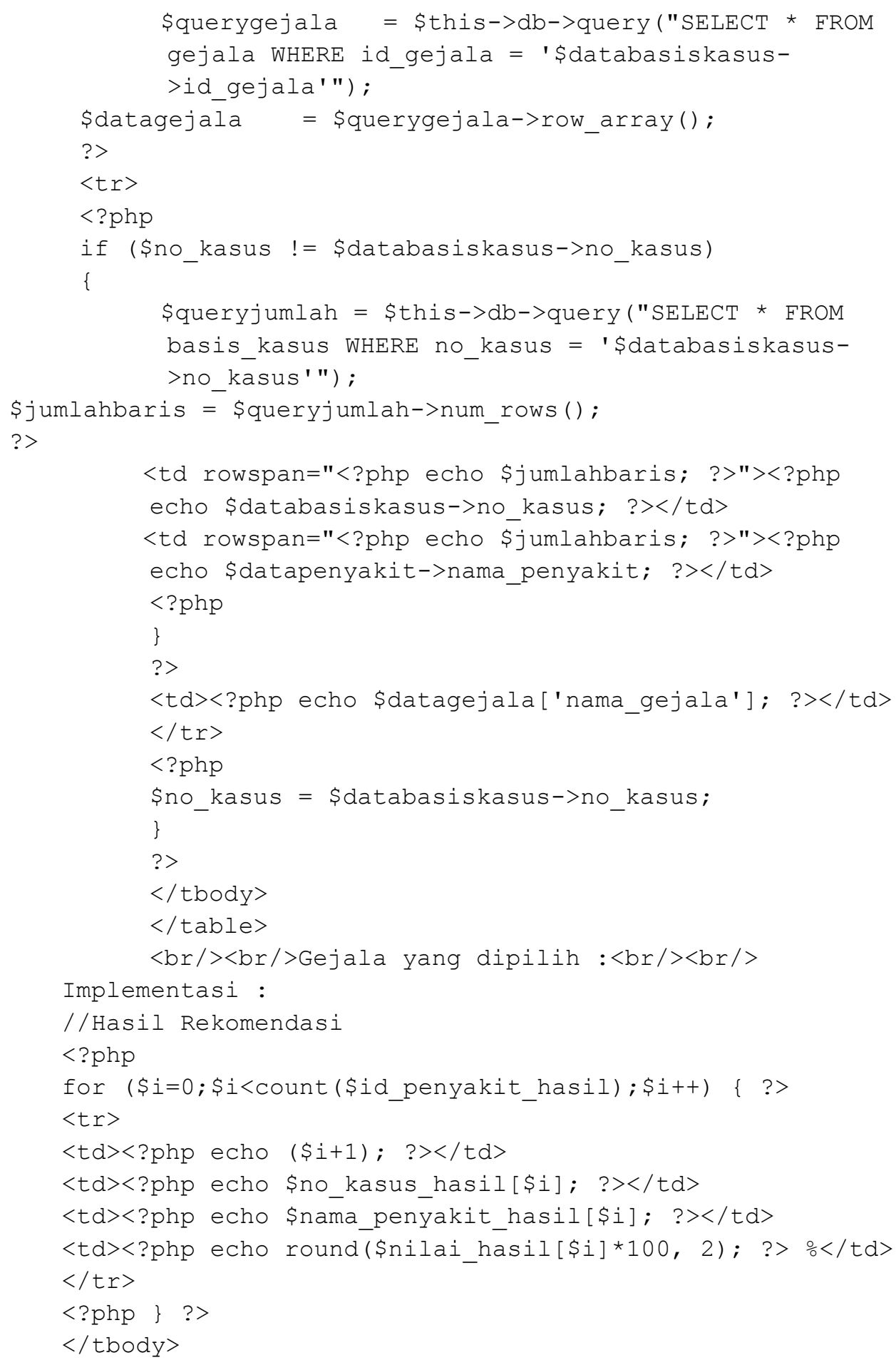




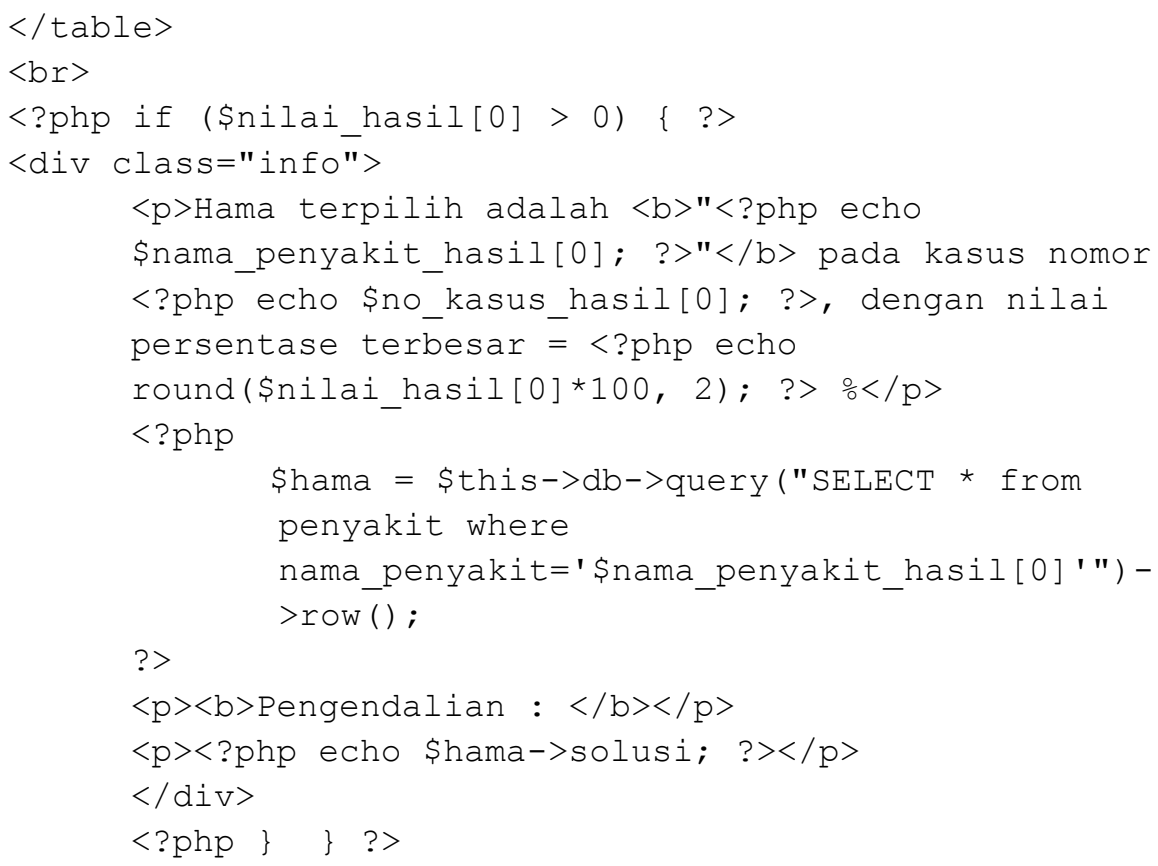

\subsection{Implementation on System}

a. Display of Main Menu

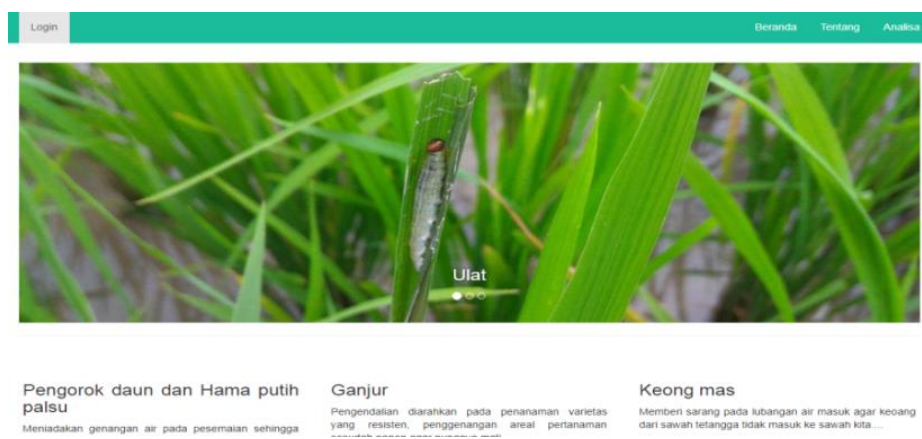

Figure 3.1 Main Menu

Figure 3.1 shows the main menu in system, there are options for login and analysis 
b. Display of Admin Login

\section{Login}

\begin{tabular}{|l|}
\hline admin \\
\hline \\
Masuk \\
\hline
\end{tabular}

Figure 3.2 Login display

Figure 3.2 shows the login menu for admin, the admin is an expert or extension agent og agriculture

c. Display of Data Menu of pest

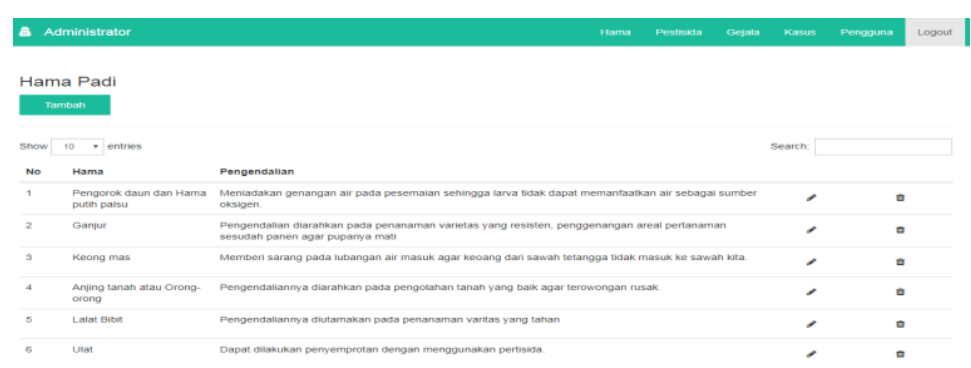

Figure 3.3 menu of pest data

Figure 3.3 shows the data menu of pest. All pests that attacked the rice are shown in this menu. If there are the change of quantity and kind of pest, the administrator must firstly login.

d. Display of pesticide Data

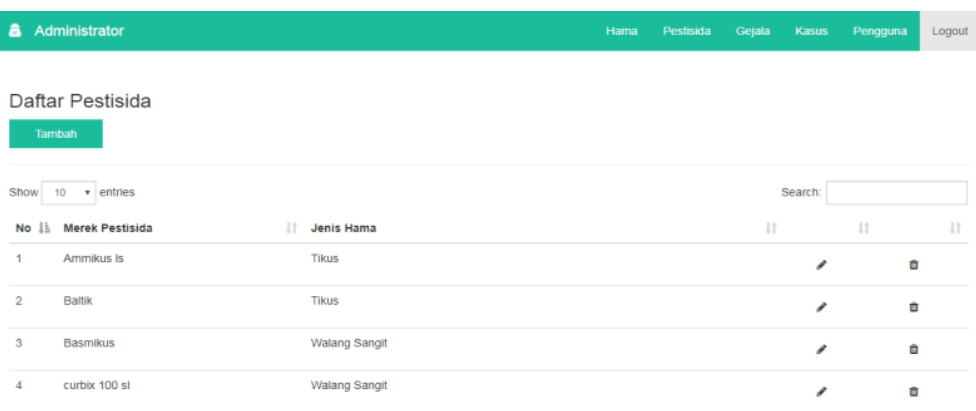

Figure 3.4 Display of pesticide Data 
Figure 3.4 shows the pesticide data. This menu consists of all pesticide data which used to get rid of rice pests.

e. Display of Data Menu of Sympton

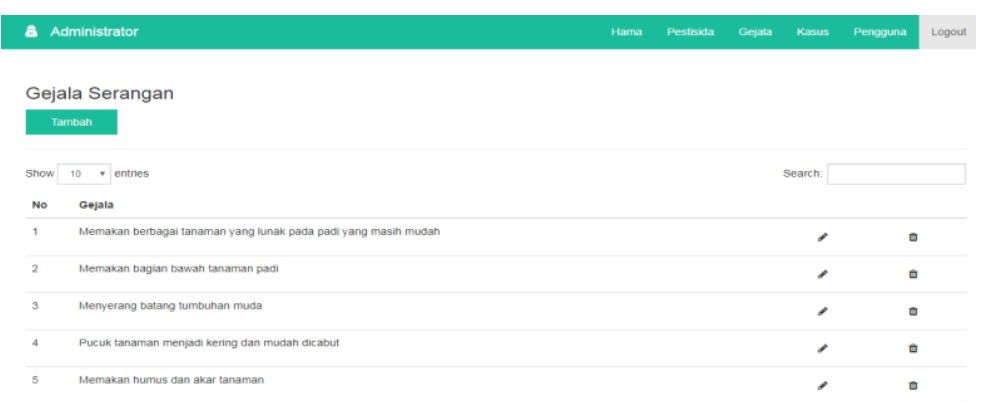

Figure 3.5 Display of Symptom Data

Figure 3.5 shows the symptom data. This Display consists of the symptom of rice pests.

\section{f. Display of Analiyze Menu}

\begin{tabular}{|l|l|}
\hline Login & Beranda Tentang Analisa \\
\hline Analisa \\
\hline Pilih Gejala \\
\hline$\square$ Daun menjadi putih \\
\hline$\square$ Bij menjacil hampa \\
\hline$\square$ Terdapat gulunganikantung pada daun \\
\hline$\square$ Pertumbuhan daun padi itidak normal \\
\hline$\square$ Terdapat terowongan di bawan tanah \\
\hline$\square$ Daun hanya tersisa rangka \\
\hline$\square$ Daun gugur \\
\hline
\end{tabular}

Figure 3.6 Display of Analyze Menu

Figure 3.6 shows the analyze menu. It consists of the process counting methodon Case Based Reasoning. 
g. Display of Analyze Result

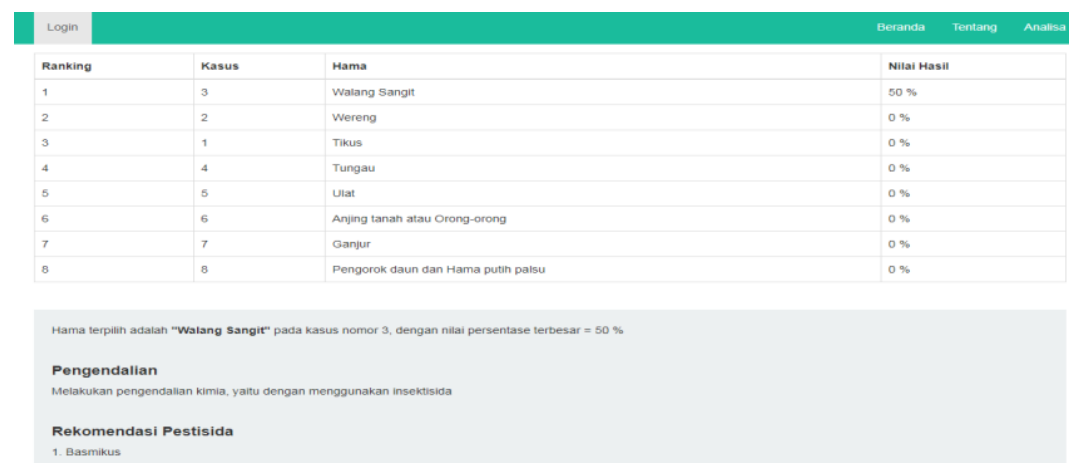

Figure 3.7 Display of Analyze Result

Figure 3.7 shows menu of result analyze. It consistsof the result of process counting method on Case Based Reasoning.

\section{Conclusion and Suggestion}

\subsection{Conclusion}

The making of decision support system to decide the kind of pesticide using Web with Case Based Reasoning (CBR), can help the farmer who are in farmer group for deciding the kind of pesticide will use. For the extension agents of agriculture, it can help them to easily inform the kind of pesticide to the farmer groups.

\subsection{Suggestion}

After the development process of Decision Support System of Selecting Pesticide for Rice Pests using Web-based Case-Based Reasoning (CBR) Method, we suggest that the system should be built and developed to more modern mobile application.

Acknowlegment. The writers say deep thanks to all stakeholder who given us support and motivation so we can fulfill and implement the result of research successfully.

\section{Reference}

[1] Suhartono, "Dampak Pestisida terhadap Kesehatan," Pros. Semin. Nas. Pertan. Organik, pp. 15-23, 2014.

[2] M. Kartikasari, P. B. Santoso, and E. Yudaningtyas, "Penerapan Case Based Reasoning pada Sistem Pendukung Keputusan Penanganan Komplain Penyewa Mall,” J. EECCIS, vol. 9, no. 2, pp. 138-143, 2015.

[3] T. Putri, D. Andreswari, and R. Efendi, "Implementasi Metode CBR (Case-Based Reasoning) Dalam Pemilihan Pestisida Terhadap Hama Padi Sawah Menggunakan Algoritma K-Nearest Neighbour (K-NN) (Studi Kasus Kabupaten Seluma),” J. Rekursif, Univ. Bengkulu, vol. 4, no. 1, pp. 80-92, 2016. 
[4] "Membuat Sistem Pakar Jauh Lebih Besar Dari Pada Pembuatan Sistem Biasa . Pakar Digunakan Untuk Memecahkan Masalah Yang Memang Sulit Untuk Dipecahkan Dengan Pemrograman Biasa ,Mengingat Biaya Yang Diperlukan Untuk,” Coding J. Komput. dan Apl. Untan, vol. 05, no. 03, 2017.

[5] A. Cucus, "Implementasi CBR dalam Penentuan Obat ( Studi yang Tepat Bagi Pasien Kasus Resep,", 2005.

[6] B. S. Wicaksono and A. Romadhony, "Analisis dan Implementasi Sistem Pendiagnosis Penyakit

Tuberculosis Menggunakan Metode Case-Based Reasoning," Eminar Nas. Apl. Teknol. Inf., pp. 22-28, 2014.

[7] A. R. Pahlawan et al., "Implementasi Case Based Reasoning Untuk Sistem Diagnosis," pp. 155-162, 2017. 